\title{
Bear farms in Lao PDR expand illegally and fail to conserve wild bears
}

\author{
Emily Livingstone and Chris R. Shepherd
}

\begin{abstract}
Bear farms, established for the extraction of bile from live bears, have unknown effects on the conservation of bears in Asia. Whilst some major bile producing countries have tightened legislation on this practice, traders have responded by establishing bile extraction facilities in countries with weaker legislation. We conducted a survey of all known facilities in Lao PDR through direct observation or examination of governmental and non-governmental records, and documented the birth and rapid growth of this industry since the first farm was established in 2000 . We also obtained trading values for gall bladders from wild bears in Lao PDR from literature, databases and direct observation. The number of farmed bears tripled from 2008 to 2012. In 2012121 Asiatic black bears Ursus thibetanus and one sun bear Helarctos malayanus were kept on 11 commercial facilities. Evidence suggests that all bears were wild caught domestically or illegally imported internationally, in violation of national and international law. Moreover, some bile from these farms was being illegally exported internationally. Farmed bile availability has apparently not diminished the demand for wild bile, as the market value has increased dramatically since 2000. We suggest that bear farming in Lao PDR may be increasing the incentive to poach wild bears.
\end{abstract}

Keywords Asiatic black bear, bear bile, CITES, gall bladders, sun bear, Traditional Chinese Medicine, wildlife farming, wildlife trade

\section{Introduction}

Tnternational trade of bears and bear products is viewed as 1 the most imminent threat to Asian bear populations (Foley et al., 2011; Garshelis, 2011). Asiatic black bears Ursus thibetanus are declining across at least $60 \%$ of their range, including all of South-east Asia, with local extirpations looming in Vietnam and Bangladesh (Garshelis \& Steinmetz, 2008; Garshelis, 2011). Sun bears Helarctos malayanus, thought to have declined by $>30 \%$ over the past 30 years, have recently been extirpated from Bangladesh, possibly from China, and extirpation could be

Emily Livingstone and Chris R. SHePHeRd (Corresponding author) c/o TRAFFIC Southeast Asia, Unit 3-2, 1st Floor, Jalan SS23/11, Taman SEA, 47400 Petaling Jaya, Selangor, Malaysia. E-mail chris.shepherd@traffic.org

Received 9 December 2013. Revision requested 11 November 2013.

Accepted 21 May 2014. First published online 29 October 2014. imminent in Vietnam (Fredriksson et al., 2008; Islam et al., 2010; Chen \& Wang, 2013).

Asiatic black bears (hereafter black bears) and sun bears are sympatric in Lao People's Democratic Republic (hereafter Lao PDR). In recent years, despite their global and national protected status, the role of Lao PDR in the trade in bears has grown rapidly and the country's wild bear populations are in decline (Scotson, 2010, 2012; Foley et al., 2011). Bears are traded domestically and internationally with China, Thailand and Vietnam, as parts (namely paws and gall bladders) and live cubs (Mills \& Servheen, 1991; Duckworth et al., 1999; Nooren \& Claridge 2001; Foley et al., 2011). Both species are categorized as Vulnerable on the IUCN Red List (Garshelis \& Steinmetz, 2008; Fredriksson et al., 2008). In Lao PDR the only national legislation concerning bears is the Wildlife and Aquatic Law, 2007, which classes both bear species as Category 1 (Prohibition): all hunting, catching and possession of bears is illegal, as is removal and/or possession of carcasses, parts and organs. Lao PDR became a Party to CITES in 2004 (both species are on Appendix I). Under Appendix I species are recognized as being threatened with extinction and affected or at risk of being affected by trade. International trade is forbidden except in exceptional circumstances, with appropriate authorization, when the purpose is non-commercial.

Bile from bear gall bladders has been used in Traditional Chinese Medicine for $>1,000$ years, and has proven medicinal qualities (Feng et al., 2009). Illegal hunting of bears for their gall bladder is fuelled largely by demand from China (Foley et al., 2011). This demand has also led to the development of an industry to extract bile from captive-held bears without killing them. Although this industry may have developed as a means to obtain and sell more easily a product that was in high demand, the conservation implications of this added supply of bile have been the subject of intense debate (Fischer 2004; Robinson et al., 2007; Drury 2009; Dutton et al., 2011). Here we use the term 'commercial bile' to refer to bile extracted from captive bears and 'wild bile/gall bladders' as that from a bear killed in the wild. A commercial facility is one that is trading in wildlife.

Bear farming originated in Korea in the early 1980s and subsequently spread throughout China and Vietnam. Increasing pressure from international conservation and welfare groups on the major bile producing countries, South Korea, China and Vietnam, has had some success in discouraging this practice. Husbandry of bears for bile extraction was outlawed in Vietnam in 2006. However, 
many farms continue to operate illegally (Nguyen, 2006; Foley et al., 2011). Prohibition in Vietnam was followed by the appearance of farms in Lao PDR and Myanmar, where weaker legislation, lax law enforcement, low public awareness of conservation and animal welfare concerns, and limited international scrutiny, has allowed the industry to grow unchallenged (Foley et al., 2011; Free The Bears, pers. comm., 2012). Neither of these countries are significant consumers of bear bile products. However, they both border China, which is the primary consumer (Dutton et al., 2011). Lao PDR also shares a border with Vietnam, which is second to China in use of bear products (Foley et al., 2011). The majority of bear farms in Lao PDR and Myanmar are reportedly owned by people of Chinese or Vietnamese origin (Foley et al., 2011; Free The Bears, pers. comm., 2012). Lao PDR has been identified as a key source of bear cubs for stocking bear farms in China and Vietnam (Mills \& Servheen, 1991; Nguyen, 2007; Robinson et al., 2007; Scotson, 2010; Vu, 2010; Foley et al., 2011; Scotson, 2012).

In Lao PDR The Wildlife and Aquatic Law, 2007, applying to all local and international individuals and organizations, states that any establishment of a commercial bear farm requires permission from the Prime Minister's office following submission of a recommendation from the Ministry of Natural Resources and the Environment. The Department of Forest Resource Management, within the Ministry, should provide an advisory role for these permissions and should conduct regular inspections of facilities (Article 62; Wildlife and Aquatic Law, 2007). Keeping of bears for 'household purposes' also requires permission from the Ministry (the law does not include a definition of 'commercial' or 'household purposes'). For a bear farm in Lao PDR to be operating legally the bears cannot be of direct wild origin. However, with the appropriate official permissions trade in bears and bear parts is permitted if they are sourced from second generation $\left(\mathrm{F}_{2}\right)$ stock. The Ministry is also the CITES Management Authority of Lao PDR, and therefore responsible for its implementation. Under the Convention international trade for commercial use is forbidden. As such, bears cannot be legally imported from other countries to stock Lao facilities.

The relationship, if any, between the availability of commercially produced bile and trends in wild bear populations is difficult to determine because of poor monitoring programmes for Asian bears and the complexity of factors that affect them. However, no nation rearing captive bears for bile extraction has documented any conservation benefits of this practice and some studies indicate that it could increase the public demand for wild products (Drury, 2009; Dutton et al., 2011). In China the number of captive bears rose to $>10,000$ in 15 years $(\mathrm{Li}, 2004)$, whereas in Sichuan, a major bile-producing province, wild populations of bears have rapidly declined as a result of poaching for parts, primarily gall bladders (Liu et al., 2009, 2011). In Vietnam farmed bears, all of wild origin, numbered $>4,000$ by 2007 , and numbers of wild bears in the country have fallen to low levels (Nguyen, 2007; Robinson et al., 2007). Likewise, bear farming did not prevent the near extirpation of bears in South Korea; the population persists only with the aid of reintroductions (Han, 2006).

The objectives of our study were to (1) document the growth, current number, and size of bear farms in Lao PDR, and potential for captive breeding; (2) record violations of national and international laws, such as harvesting of wild bears to stock facilities, extracting bile from wildcaught or first generation captive stock, trading in bear parts from wild bears, or supplying bile products for international export; and (3) explore the economic consequences of introducing commercial bile into a market traditionally dominated by bile from wild bears.

\section{Methods}

We collected records from published and unpublished literature and government documents referring to numbers of bear farms and numbers of bears on these facilities in Lao PDR. During July-August 2012 we visited five of these facilities to count the bears and assess conditions for breeding and cub-rearing. We also looked for unrecorded bile farms in potential locations, based on size of town/city and geographical potential for international trade (i.e. proximity to the borders with Vietnam and China). Facility searches involved making inquiries at major transport hubs (bus stations, taxi stations), markets, hotels, tourist agencies and pharmacies (including traditional medicine stalls). The survey team were Lao speaking westerners posing as tourists seeking to purchase bear bile.

Information was elicited from staff and owners with regard to origin of the bears and captive breeding. To identify whether or not bears were being bred we asked owners, looked for the presence of breeding facilities (e.g. bears in pairs or groups, large mixing areas, den areas), and examined government registration documents where possible. We recorded indications that bears were derived from the wild, such as missing limbs (presumed snare injuries), reports from owners and government records.

We obtained trading values for 1991-2012 for wild bear gall bladders and live cubs from available literature, unpublished data, and personal observations. Many values were from incidental observations of domestic market trading. Other values are mean hunter trading values recorded during rural interview surveys conducted in the north and south of Lao PDR during 2010-2012 (Scotson, 2010, 2012). Trading values for cubs and gall bladders were not noticeably different between black bears and sun bears and were therefore pooled in the analyses. 


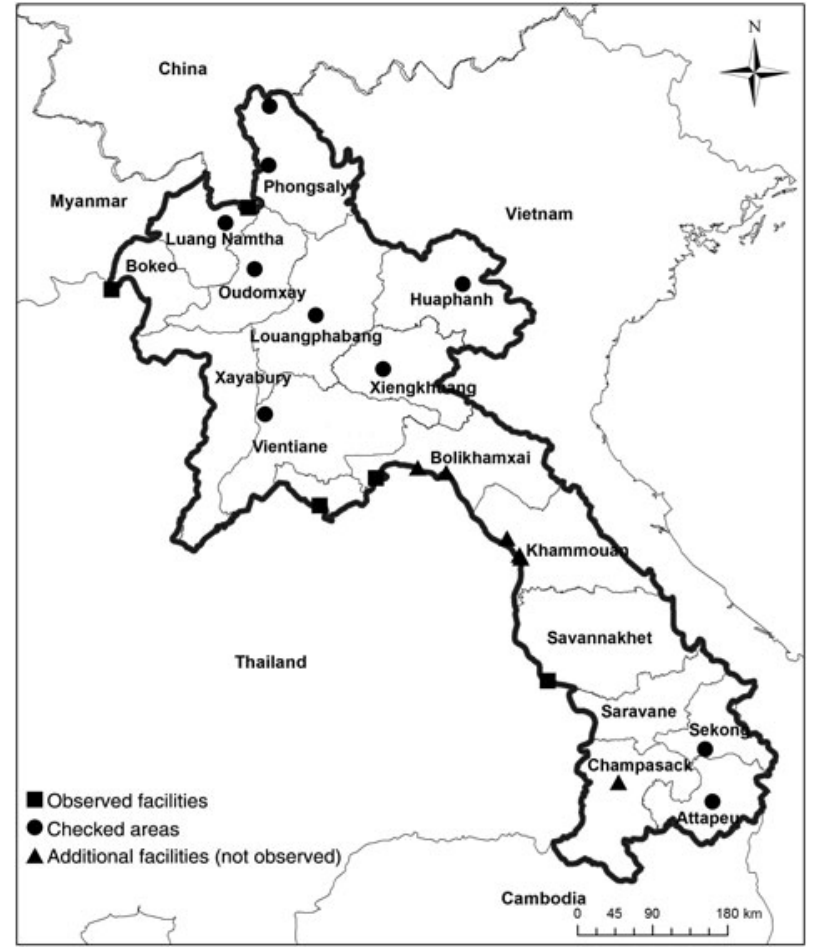

FIG. 1 Locations of so-called bear farms in Lao PDR and of other locations searched during our survey during July-August 2012.

\section{Results}

\section{Number of farms and bears}

The oldest bear farm known in Lao PDR is in Vientiane, established in 2000 (Fig. 1). We could find no records of bear farms before then. Eight more farms opened by 2008-2009, and a further two in 2010 and 2012, respectively. It is possible that at least some of these farms were undetected prior to 2008 and that the apparent spurt of openings at this time was in part an artefact of improved record keeping. Government records in 2009 indicate a total of 45 bears held in 5 farms ( 44 black bears and one sun bear). Recorded bear numbers have increased at an mean annual rate of $41 \%$ (Fig. 2). Of the five facilities we visited only one was previously unrecorded (Don Savannh Casino in Bokeo Province; Table 1). Following our searches for bile farms in major towns and cities we also located information, from government records, regarding four other farms in small towns and remote areas that we had not visited.

Summarizing all records and observations, and excluding those deemed unreliable, we documented 11 facilities holding bears in Lao PDR as of August 2012 (not including a bear rescue centre in Louangphabang and Ban Keun Zoo, Vientiane). We directly observed 66 black bears in four facilities (Table 1). Bears held in Ban Tapabat, south of Vientiane could not be observed directly; a guard outside

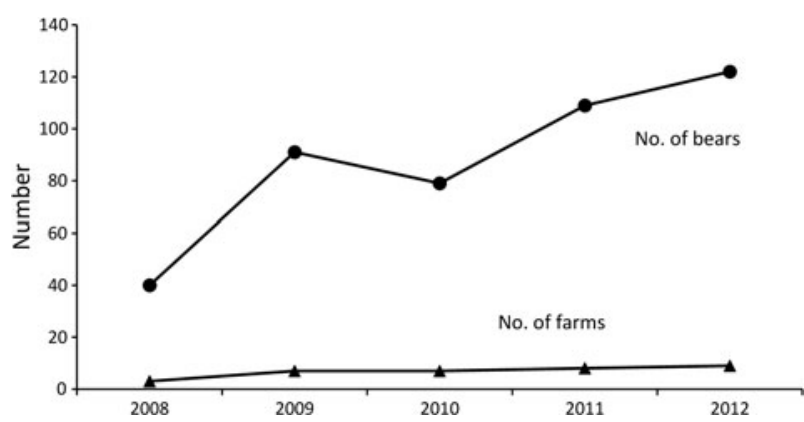

FIg. 2 Total number of individual bears (all Asiatic black bear Ursus thibetanus) and number of bear farms recorded from 2008 to 2012 (see text for details).

told us there were 15 individuals (comparable to the 2010 government report of 10 bears). We were unable to locate one farm (Pakxe) but government sources reported it to be still operating, with at least 10 bears (last known figure from 2010; Free The Bears, pers. comm.). Registration documents of a further four farms report 27 black bears: (1) Phonsaat Village, Hinbone, Khammouan Province (five bears); (2) Nongboua-noi Village, Hinbone District (five bears); (3) Phongxai Village, Pakxan, in Bolikhamxai Province (15 bears); and (4) Xaysavang, Paksong, Bolikhamxai (two bears). Another 3-4 bears (2-3 black bears and one sun bear) were reportedly kept at Muang Tong Tiger Farm, Thakhek, Kammouan Province (Vongkhamheng, pers. obs., 2011). We found only five other records of sun bears in three facilities since 2008: Vientiane $(\mathrm{n}=3)$, Louangphabang $(n=1)$ and Boten $(n=1$; ACRES, pers. comm., 2011; Free The Bears, pers. comm., 2012; TRAFFIC, pers. comm., 2010, 2012).

Nine facilities were extracting bile for commercial sale. Two facilities were holding bears but did not appear to be extracting bile: Don Savannh Zoo in Bokeo Province and Muang Tong tiger farm in Kammouane Province. At Don Savannh Zoo reception staff in the adjacent casino told us that bile was not extracted but that wild gall bladders and paws could be bought to order, and they provided a telephone number for ordering. The owner of Muang Tong tiger farm would not allow us to enter but told us that bile was not extracted from bears and suggested we visit the bile farm in Vientiane.

No facilities appeared capable of breeding bears. In all but one case (Don Savannh Zoo), all bears were housed in individual enclosures. Owners/staff of Boten and Vientiane facilities reported that all bears come from the forests of Lao PDR. The owner of Savannaket farm told us that 50\% were wild caught and 50\% captive bred, coming from either Lao PDR or Vietnam. Bears with missing limbs (assumed to be snare injuries from wild capture) were recorded in Vientiane, Savannaket and Don Savannh Zoo $(\mathrm{n}=6$ since 2000). Registration documents for three facilities (Nongboua-noi Village in Hinboun District, Ban Thaphabat in Bolikhamxai 
TABLE 1 Bear bile extraction facilities that we visited in Lao PDR during July-August 2012, with the number of Asiatic adult black bears Ursus thibetanus and cubs $<1$ year old seen, evidence of any snare injuries, volume and price of bile sold directly to customers, nationality of owners and any comments. There was no evidence of breeding facilities at any of the locations.

\begin{tabular}{|c|c|c|c|c|c|c|}
\hline Town (Province) & $\begin{array}{l}\text { No. of } \\
\text { bears }\end{array}$ & Cubs & Injuries & Bile (USD) & Owners & Other comments \\
\hline $\begin{array}{l}\text { Boten (Luang } \\
\text { Namtha) }\end{array}$ & 22 & 1 & $\begin{array}{l}\text { All bears in very } \\
\text { poor condition }\end{array}$ & $\begin{array}{l}6 \text { (per vile of } \\
\text { flakes) }\end{array}$ & Chinese & $\begin{array}{l}\text { Owner reported all bears wild caught in Lao } \\
\text { PDR }\end{array}$ \\
\hline $\begin{array}{l}\text { Thaphabat } \\
\text { (Bolikhamxai) }\end{array}$ & 15 & Unknown & Unknown & $10\left(\right.$ per $\left.\mathrm{cm}^{3}\right)$ & $\begin{array}{l}\text { Lao/ } \\
\text { Chinese }\end{array}$ & $\begin{array}{l}\text { Tiger farm with c. } 50 \text { tigers, } 80 \mathrm{~km} \mathrm{~S} \text {. of } \\
\text { Vientiane. No visual inspection (report is } \\
\text { from security guard) }\end{array}$ \\
\hline $\begin{array}{l}\text { Savannakhet } \\
\quad \text { (Savannakhet) }\end{array}$ & 11 & 0 & $\begin{array}{l}2 \text { with missing } \\
\text { limbs }\end{array}$ & $19\left(\right.$ per $\left.\mathrm{cm}^{3}\right)$ & Vietnamese & $\begin{array}{l}\text { Owner reported bears } 50 \% \text { wild } / 50 \% \text { captive } \\
\text { bred from Lao PDR \& Vietnam }\end{array}$ \\
\hline $\begin{array}{l}\text { Vientiane } \\
\quad \text { (Vientiane) }\end{array}$ & 25 & 0 & $\begin{array}{l}1 \text { with missing } \\
\operatorname{limb}\end{array}$ & $19\left(\right.$ per $\left.\mathrm{cm}^{3}\right)$ & Vietnamese & $\begin{array}{l}\text { Owner reported that all wild caught in Lao } \\
\text { PDR }\end{array}$ \\
\hline $\begin{array}{l}\text { Don Savannh } \\
\text { Casino 'Zoo' } \\
\text { (Bokeo) }\end{array}$ & 8 & 1 & $\begin{array}{l}1 \text { cub with miss- } \\
\text { ing limb }\end{array}$ & & Chinese & $\begin{array}{l}\text { No sign of bile extraction; Casino staff told } \\
\text { us we could order wild gall \& paws for } \\
\text { purchase }\end{array}$ \\
\hline
\end{tabular}

and Xaysavang, Paksan in Bolikhamxai) state that bears were sourced within Lao PDR. In the absence of breeding facilities we presumed these to be wild caught.

We estimate there were at least 122 captive bears in Lao PDR in August 2012. According to records, captive bear numbers increased during 2008-2012 at a mean annual rate of $21 \%$ (Fig. 2 ).

\section{Law violations}

We documented numerous infringements of national laws and international treaty obligations. These involved five general categories of violations. Eight of the nine extraction facilities we investigated, and one holding bears without extracting bile, were in violation of at least one category (Table 2). We could not assess the Pakxe facility.

\section{Trading values of wild gall bladders and cubs}

We collected 41 trading values for wild gall bladders and 35 for cubs during 1991-2012 (all in-country). Trading values from rural interview surveys (from Scotson 2010, 2012) are poacher trade prices. Other values, collected from incidental reports and our personal observations, were prices reflective of local market trading. The mean trading price of cubs was $\times 2.6$ higher and gall bladders $\times 180$ higher during $2010-2013$ than during 1991-1993, but with variable trends attributable to small samples and missing data for some years (Fig. 2).

\section{Discussion}

\section{Source of farmed bears}

The number of bears on farms in Lao PDR tripled during 2008-2012, with no evidence that any of these bears were being kept legally. All of the captive bears appeared to be either wild caught in Lao PDR or transported there from another country, most likely Vietnam. Given the trend in Vietnam farms to only use wild stock (Nguyen, 2007), it seems likely that all captive bears in Lao PDR are first generation wild caught bears.

A provision in the Wildlife and Aquatic Law, 2007, which allows trade in F2 stock specimens, parts and derivatives, is a major loophole. In a system with poor monitoring and record-keeping the loophole enables farmers to hide the illegality of their operations (Matt Hunt, pers. comm., 2012). In the unlikely scenario that all bears were captive bred in another country, they are still held illegally in Lao PDR in the absence of CITES permits. Since 1975 there has been only one CITES permit issued for the import of wild-sourced black bears from Vietnam to Lao PDR (two bears in 1999 for the purpose of 'Circus and Travelling exhibition'; CITES, 2014). The CITES National Legislation Project rated the national legislation in Lao PDR as Category III, meaning that it does not meet the requirements necessary to effectively implement CITES (CITES, 2012). Given the inadequate governance of trade in wildlife across international borders in this region, it is reasonable to assume that any imported bears were brought in illegally. It also remains possible that all farms were stocked entirely with bears originating from Lao PDR, which still has extensive forests to support populations of wild bears (Scotson, 2010, 2012).

\section{Potential consequences of the growing bear} bile industry

The increasing availability of commercial bile, and marketing targeted at the Lao public, is presumably intended to increase domestic consumer demand. Marketed at an affordable price $($ LAK $180,000 \approx$ USD 20), commercial 
TABLE 2 Observed violations of national and international legislation concerning bears in bile extraction facilities in Lao PDR.

\begin{tabular}{|c|c|c|c|c|}
\hline Violation & No. of facilities & Facilities & Law(s) violated & Comments \\
\hline $\begin{array}{l}\text { Wild offtake to } \\
\text { stock farms }\end{array}$ & 8 (1 now closed) & $\begin{array}{l}\text { Vientiane; Louangphabang } \\
\text { (now closed); Boten; Don } \\
\text { Savannh Zoo (Savannakhet); } \\
\text { Nongboua-noi Village } \\
\text { (Hinboun District)*; } \\
\text { Vannaseng, (Ban Tahprabat), } \\
\text { Bolikhamxai*; Xaysavang }\end{array}$ & $\begin{array}{l}\text { The Wildlife \& Aquatic } \\
\text { Law, 2007; hunting, catch- } \\
\text { ing \& possession of bears is } \\
\text { illegal, as is removal \&/or } \\
\text { possession of carcasses, } \\
\text { parts \& organs }\end{array}$ & $\begin{array}{l}\text { Records from } 2008-2012 \text { include } 16 \text { observations of bear cubs of } \\
<1 \text { year old in Vientiane }(\mathrm{n}=2) \text {, Louangphabang }(\mathrm{n}=4) \text {, Boten } \\
(\mathrm{n}=9) \text { \& Don Savannh Casino, Bokeo }(\mathrm{n}=1) \text {. In absence of } \\
\text { breeding facilities, these bears are probably wild caught. Missing } \\
\text { limbs recorded since } 2000 \text { for } 6 \text { bears in Don Savannh Zoo }(\mathrm{n}= \\
\text { 1) \& Vientiane }(\mathrm{n}=3) \text { \& Savannakhet }(\mathrm{n}=2) \text { facilities are pre- } \\
\text { sumed to be snare injuries from wild capture. }\end{array}$ \\
\hline
\end{tabular}

First generation wild stock used for commercial

bile extraction

Trading in wild bear products (Paksong, Bolikhamxai) ${ }^{\star}$

Vientiane; Louangphabang (now closed); Boten; Don Savannh Zoo; Savannakhet

Vientiane; Don Savannh Zoo

Catering to international market

International movement of live bears
The Wildlife \& Aquatic Law, 2007; trade in bears \& bear parts is permitted only if sourced from animals bred in captivity for at least 2 generations

The Wildlife \& Aquatic Law, 2007; hunting, catching \& possession of bears is illegal, as is removal \&/or possession of carcasses, parts \& organs

CITES; international trade is forbidden except in exceptional circumstances, with appropriate authorization, when the purpose of the import is not commercial

CITES; forbids import of bears for commercial use. Vietnam Governmental

Decree 32/2006/ND-CP illegal to transport bears
No breeding in any bile extraction facility in Lao PDR; in all but one case (Don Savannh Zoo) bears were housed in individual enclosures. Owners of Boten, Louangphabang, Vientiane \& Savannakhet facilities claim bears are of wild origin from Lao.

At Don Savannh Zoo wild gall bladders \& bear paws can be ordered (Table 1). Owner of Vientiane facility told us they periodically process wild bears; also selling gall bladders \& paws (most recently in July 2012).

In Louangphabang (farm now closed) we discovered an outlet for bile, which is transported weekly from Vientiane. Bile was advertised for sale \& Vietnamese owner told us they supply a Chinese restaurant in town that caters to Thai, Korean \& Chinese tourists. Boten facility, on Chinese border, sells products from outlet labelled with Chinese text. In Savannakhet, a group of Chinese tourists observed purchasing bile from 3 bears (freshly milked). Vials were wrapped in black masking tape to hide contents \& they informed us they were transporting it to China overland.

Owner of Savannakhet facility claims some of the bears originated from Vietnam. Note that in unlikely case that no cubs are wild caught in Lao PDR then in the absence of breeding facilities \& CITES permits, all bears have been imported illegally.

${ }^{*}$ Registration documents state that bears were sourced within Lao PDR (presumed to be wild caught as lack of breeding).

${ }^{* *}$ Facilities not observed \& no records located. 


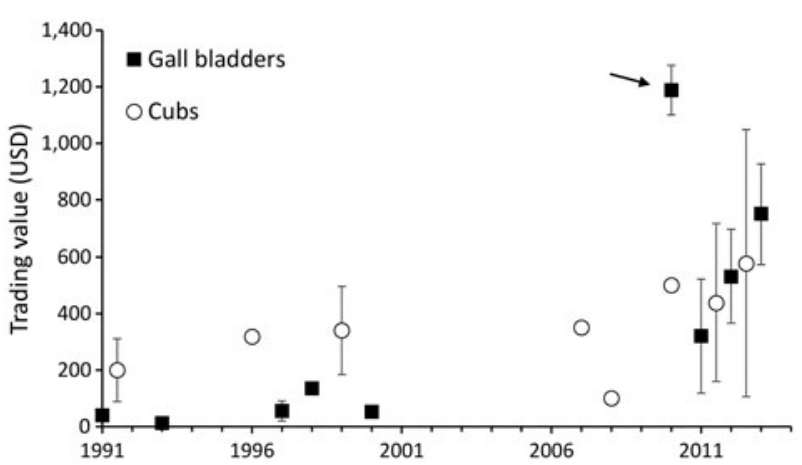

FIG. 3 Mean \pm SD trading values for wild harvested bear gall bladders and live cubs of Asiatic black bears and sun bears (pooled as there was no discernible difference in value between species). Values represent rural market (poacher level) trading and urban market (middle-man, domestic) trading. All values pre-2010 are urban level. After 2010, values for cubs are a mixture of rural and urban level trading. One extreme value for a cub of USD 3,250 is excluded from 2012 (because of the effect on the SD) but is included in the in-text mean of USD 8oo. After 2010 gall bladder values are all from rural level market trading except for two values in 2011 (indicated by arrow), which are from urban market trading. Sources: Mills \& Servheen (1991); Salter (1993); Nash (1997); Tizard et al. (1997); Nooren \& Claridge (2001); Scotson (2010, 2012); L. Scotson, unpubl. data.

bear bile is advertised to the Lao public via radio broadcasts, magazine and newspaper articles, leaflets, business cards and posters. This probably gives consumers the impression that the product is legal (it would be if the farms were operating legally).

Some bile consumers may not view commercial bile as an acceptable substitute for wild bile (Sas-Rolfes \& Conrad, 2010; Dutton et al., 2011) and use of commercial bile may act as an entry-level wildlife product to use of wild bile (Bulte \& Damania, 2005; Drury, 2009). Thus, as the consumer market for commercial bile grows, a proportion of this group may at some point become consumers of wild bile. Consumers may also react with an increased willingness to pay for the wild product (Fischer, 2004; Dutton et al., 2011) because they perceive it to be more valuable than commercial bile, in more restricted supply, and/or may become convinced of its efficacy through advertising or use of the farmed product. This may explain the increase that we observed in the price of the wild product, coincident with the increase in availability of farmed bile (Figs $2 \& 3$ ). Alternatively, the increasing price may have resulted from declining bear populations and hence scarcity of the wild product, and this may have prompted the establishment of commercial facilities that produce an affordable and readily available product.

Many wildlife taxa are farmed commercially (Mills et al., 1995; Revol, 1995; Meacham, 1997; Li, 2004; Han, 2006; Nguyen 2007; Brooks et al., 2010; Foley et al., 2011; Lyons \& Natusch, 2011; Nogueria \& Nogueira-Filho, 2011). The success of farming depends on a number of factors, such as the biology of the animal, the quality of husbandry, and the intended use of a given product (material, food, medicine). Perhaps most importantly, success may be determined by consumers' socio-economic status, cultural beliefs and willingness to use the commercial product in lieu of the wild product (Fischer, 2004; Dutton et al., 2011). In some cases commercial farming could be considered successful in terms of market profitability and biological sustainability (Revol, 1995; Lapointe et al., 1997). In the case of wildlife consumed as food and medicine, however, consumers may be willing to pay more to purchase an illegal wild product that they perceive to be of superior quality (Anderson, 1997; Tong, 2007; Gratwicke et al., 2008; Li et al., 2008; Drury, 2009; Brooks et al., 2010).

Research into the dynamics of trade in threatened wildlife, and the market forces at play, is generally considered lacking in both quality and quantity (Garshelis, 1997; Schneider, 2008). Supply-side economic theory predicts that an increase in market supply of a given product should help satisfy consumer demand and decrease its market value (Fischer, 2004; Bulte \& Damania, 2004; Sas-Rolfes \& Conrad, 2010). This does not appear to have been the case for wild bear bile in Lao PDR. Following the introduction of a supply of commercial bile in 2000 , the national market value of wild bile rose dramatically ( $>$ x10 since 1991). Moreover, we uncovered evidence that some of the farmed bile was being exported to other countries (Table 2).

The markets for wild and commercial bile may mostly operate independently of each other, with separate consumer bases, or could interact in complex ways, with effects on wild bear populations (Abbot \& van Kooten, 2011; Moyle, 2013; Phelps et al., 2013). Introduction of a commercial product into the market place may trigger strategic responses from traders of wild products and the nature of this competition could determine the outcome for wild populations (Bulte \& Damania, 2005). Traders in high value wildlife products, often controlled by organized international criminal networks (Meacham, 1997; Zimmerman, 2003), may dominate the wild market, with the power to fix prices. The extent of the mark-up of a given product is determined by both scarcity (wild population status) and the intensity of competition within the market. Traders can respond to competition from commercial products passively or actively. In the absence of consumer preference for wild bile, a passive response, in which price of the wild product declines as a result of increase in supply of the commercial product, would result in lowered incentive to poach and therefore benefit wild populations. An active competitive response could be to increase the mark-up on a wild product and to expand supply by increasing the incentive to poach. In the case where consumers had no preference for commercial compared to wild bile, an active response could be to compete more aggressively by lowering the price of the wild product (Fischer, 2004; Bulte \& Damania, 2005). 


\section{Poaching wild bears}

The impetus to poach and trade in bears and bear parts relates to market values and opportunity costs (MilnerGulland \& Leader Williams, 1992; Bulte \& Damania, 2005; Poudyal et al., 2009). In Lao PDR law enforcement is such that there is little likelihood of being punished, whereas the potential profits from poaching bears are high (Scotson, 2010). The rising market values incentivize poaching, which is probably the main driver affecting wild populations. A decline in wild populations will result in scarceness of supply and thus further fuel the increase in price (Fischer, 2004).

A market for live cubs to stock bear farms would create a further incentive for poaching. Farmers may find it more practical and cost effective to stock with wild animals than to create facilities for breeding and cub-rearing (Bulte \& Damania, 2005; Loeffler et al., 2009; Brooks et al., 2010; Lyons \& Natusch, 2011). The mean trading value of a wild bear cub in Lao PDR was USD 800 in 2012 (Fig. 3). This is probably less than the costs associated with establishing a facility suitable for captive breeding. Given the increase in the number of captive bears and the low life expectancy of these bears (rarely 15 years; Loeffler et al., 2009) we can expect that, without improved regulation or advances in captive breeding, an increasing number of bears will be wild caught to restock and expand bile extraction facilities, and this is likely to have negative consequences for the wild population.

\section{Conclusions and recommendations}

Facilities holding live bears for commercial bile extraction are commonly referred to as 'bear farms', which has the connotation of captive breeding. However, it is clear that many of the facilities that hold captive bears to obtain their bile have no breeding (Nguyen, 2007; Robinson et al., 2007; Vu, 2010; Dutton et al., 2011; Foley et al., 2011). Here we introduce the term 'bile extraction facility' to describe facilities used to obtain bile from captive bears, with no breeding, including all facilities in Lao PDR.

Based on the collective evidence obtained in this study, the bile extraction industry in Lao PDR appears to be growing despite the fact that all known facilities are thought to be operating illegally. If allowed to continue, this industry is likely to contribute to the decline of national wild bear populations by stimulating the market for wild bear bile and increasing the incentive to poach wild bears (for trade in parts and to stock farms).

We make the following four recommendations to improve conservation of bears in Lao PDR:

(1) In accordance with IUCN recommendation WCC2012-Rec-139-EN (IUCN, 2012), all illegal bile extraction facilities should be closed down, the industry should not be expanded and no more bears from the wild should be used to stock facilities. (2) The Government of Lao PDR should work with China and Vietnam, the main consumers of bear bile, to take proactive steps to ensure illegally sourced bear products are not being smuggled internationally. Individuals found illegally bringing bear products into these countries should be punished to the full extent of the law, with seizures and convictions being widely publicized so as to raise awareness and serve as a deterrent. (3) The CITES Standing Committee and the CITES Secretariat should be informed of the violations taking place between Lao PDR and neighbouring China and Vietnam and consider trade suspensions with Lao PDR until bear bile extraction facilities are closed and Lao PDR's national legislation is amended to allow the enforcement of CITES and removal of current loopholes. (4) Given the secretive and underground nature of the extraction of bear bile in Lao PDR we recommend more investigation and monitoring to determine if there are more such facilities in the country, and more assistance to authorities in shutting down these illegal operations and penalizing individuals and companies found to be involved in illegal trade of bears and bear products.

TRAFFIC have alerted the relevant authorities in Lao PDR of IUCN's call to close down bear farms and to ensure that no more bears are taken from the wild to stock such farms. They have also been made aware of the CITES resolutions and responsibilities pertaining to bears. The recommendations from this paper will be presented by TRAFFIC Southeast Asia to the CITES Management Authority of Lao PDR, with a formal offer of technical support to implement them. These recommendations will be integrated into future TRAFFIC training sessions for capacity building for Lao PDR wildlife enforcement agencies.

\section{Acknowledgements}

We thank Matt Hunt, William Schaedla and Brian Crudge for their comments, Dave Garshelis for comments and insights throughout this project, and Will Duckworth and an anonymous reviewer. We thank Hauser Bears for generously funding this study.

\section{References}

Аввотт, B. \& van Kooten, G.C. (2011) Can domestication of wildlife lead to conservation? The economics of tiger farming in China. Ecological Economics, 70, 721-728.

Anderson, E.N. (1997) Traditional medicinal values of food. In Food and Culture: A Reader (eds C. Counihan \& P. van Esterik), pp. 80-92. Routledge, London, UK. 
Brooks, E.G., Roberton, S.I. \& Bell, D.J. (2010) The conservation impact of commercial wildlife farming of porcupines in Vietnam. Biological Conservation, 143, 2808-2814.

Bulte, E.H. \& Damania, R. (2004) An economic assessment of wildlife farming and conservation. Conservation Biology, 19, 1222-1233.

Chen, W. \& Wang, D.J. (2013) Update the status of Sun Bear in Yunnan, China. Unpublished report to the International Association for Bear Research and Management.

CITES (2012) National Laws for Implementation of the ConventionNotification No. 2012/036. CITES, Geneva, Switzerland.

CITES (2013) CITES Trade Database. Http://www.unep-wcmc-apps. org/citestrade [accessed 28 October 2013].

DRURY, R. (2009) Reducing urban demand for wild animals in Vietnam: examining the potential of wildlife farming as a conservation tool. Conservation Letters, 2, 263-270.

Duckworth, J.W., Salter, R.E. \& Khounboline, K. (1999) Wildlife in Lao PDR: 1999 Status Report. Unpublished report. IUCN, Wildlife Conservation Society, Centre for Protected Areas and Watershed Management, Vientiane, Lao PDR.

Dutton, A.J., Hepburn, C. \& Macdonald, D.W. (2011) A stated preference investigation into the Chinese demand for farmed vs wild bear bile. PLOS ONE 6(7), e21243.

Feng, Y., Siu, K., Wang, N., NG, K.-M., Tsao, S.-W., Nagamatsu, T. \& Tong, Y. (2009) Bear bile: dilemma of traditional medicinal use and animal protection. Journal of Ethnobiology and Ethnomedicine, 5, 2.

Fischer, C. (2004) The complex interactions of markets for endangered species products. Journal of Environmental Economics and Management, 48, 926-953.

Foley, K.E., Stengel, C.J. \& Shepherd, C.R. (2011) Pills, Powders, Vials and Flakes: The Bear Bile Trade in Asia. TRAFFIC Southeast Asia, Petaling Jaya, Malaysia.

Fredriksson, G., Steinmetz, R., Wong, S. \& Garshelis, D.L. (2008) Helarctos malayanus. In The IUCN Red List of Threatened Species. v. 2011. Http://www.iucnredlist.org [accessed 23 April 2012].

Garshelis, D.L. (1997) The arrogance of ignorance-a commentary on the bear trade. International Bear News, 6, 4-6.

Garshelis, D.L. (2011) Session 1: status of the World's bears-threats and conservation measures. International Bear News, 20, 6-11.

Garshelis, D.L. \& Steinmetz, R. (2008) Ursus thibetanus. In The IUCN Red List of Threatened Species. v. 2011.2. Http://www.iucnredlist.org [accessed 23 April 2012].

Gratwicke, B., Mills, J., Dutton, A., Gabriel, G., Long, B., Seidensticker, J., et al. (2008) Attitudes toward consumption and conservation of tigers in China. PLoS ONE, 3(7), e2544.

HAN, S.H. (2006) The status of bears and restoration projects on the Korean Peninsula. In Understanding Asian Bears to Secure their Future (eds Japan Bear Network), pp. 102-106. Japan Bear Network, Ibaraki, Japan.

Islam, A., Bin Muzaffar, S., Aziz, A., Kabir, M., Uddin, M., CHAкмA, S., et al. (2010) Baseline Survey of Bears in Bangladesh 2008-2010. Unpublished report. Wildlife Trust of Bangladesh, Dhaka, Bangladesh.

IUCN (2012) WCC-2012-Rec-139-EN: Bear Farming in Asia, with particular Reference to the Conservation of Wild Populations. Https://portals.iucn.org/docs/iucnpolicy/2012-recommendations/ en/WCC-2012-Rec-139-EN\%2oBear\%2ofarming\%2oin\%2oAsia,\% 2owith\%2oparticular\%2oreference\%2oto\%2othe\%2oconservation\% 200f\%20wild\%2opopulations.pdf [accessed 30 July 2014].

Lapointe, E., Conrad, K., Mitra, B. \& Jenkins, H. (2007) Tiger Conservation: It's Time to Think Outside the Box. IWMC World Conservation Trust, Lausanne, Switzerland.
LI, P.J. (2004) China's bear farming and long-term solutions. Journal of Applied Animal Welfare Science, 7, 71-81.

Li, Z., Ning, H. \& SAHN, S. (2008) Wildlife trade, consumption and conservation awareness in Southwest China. Biodiversity and Conservation, 17, 1493-1516.

Liu, F., McShea, W., Garshelis, D., Xiaojian, Z., Wang, D., Gong, J. \& Chen, Y. (2009) Spatial distribution as a measure of conservation needs: an example with Asiatic black bears in south-western China. Diversity and Distributions, 15, 1-11.

Liu, F., McShea, W.J., Garshelis, D.L., Zhu, X., WanG, D. \& Shao, L. (2011) Human-wildlife conflicts influence attitudes but not necessarily behaviours: factors driving the poaching of bears in China. Biological Conservation, 144, 538-547.

Loeffler, I.K., Robinson, J. \& Cochrane, G. (2009) Compromised health and welfare of bears farmed for bile in China. Animal Welfare, 18, 225-235.

Lyons, J.A. \& Natusch, D.J. (2011) Wildlife laundering through breeding farms: illegal harvest, population declines and a means of regulating the trade of green pythons (Morelia viridis) from Indonesia. Biological Conservation, 144, 3073-3081.

Meacham, C.J. (1997) How the Tiger Lost its Stripes: An Exploration into the Endangerment of a Species. Harcourt Brace, New York, USA.

Mills, J.A., Chan, S. \& Ishinara, A. (1995) The Bear Facts: The East Asian Market for Bear Gall Bladder. TRAFFIC East Asia, Cambridge, UK.

Mills, J.A. \& Servheen, C. (1991) The Asian Trade in Bears and Bear Parts. TRAFFIC-USA/WWF, Washington, DC, USA.

Milner-Gulland, E.J. \& Leader-Williams, N. (1992) A model of incentives for the illegal exploitation of black rhinos and elephants: poaching pays in Luangwa Valley, Zambia. Journal of Applied Ecology, 29, 388-401.

Moyle, B. (2013) Conservation that's more than skin-deep: alligator farming. Biodiversity and Conservation, 22, 1663-1667.

NAsh, S.V. (ed.) (1997) Fin, Feather, Scale and Skin: Observations on the Wildlife Trade in Lao PDR and Vietnam. TRAFFIC Southeast Asia, Petaling Jaya, Malaysia.

NGUYEn, X.D. (2006) The current status and conservation of bears in Vietnam. In Understanding Asian Bears to Secure their Future (eds Japan Bear Network), pp. 61-65. Japan Bear Network, Ibaraki, Japan.

NGUYEN, X.D. (2007) Bear parts trade in Vietnam and measures for its control. In Proceedings of the Fourth International Symposium on the Trade in Bear Parts (ed. D.F. Williamson), p. 61. TRAFFIC East Asia-Japan, Tokyo, Japan.

Nogueira, S.S. \& Nogueira-Filho, S.L. (2011) Wildlife farming: an alternative to unsustainable hunting and deforestation in Neotropical forests? Biodiversity and Conservation, 20, 1385-1397.

Nooren, H. \& Claridge, G. (2001) Wildlife Trade in Laos: The End of the Game. Netherlands Committee for IUCN, Amsterdam, The Netherlands.

Phelps, J., Carrasco, L. \& Webb, E.A. (2013) Framework for assessing supply-side wildlife conservation. Conservation Biology, 28, 244-257.

Poudyal, M., Rothley, K. \& Knowler, D. (2009) Ecological and economic analysis of poaching of the greater one-horned rhinoceros (Rhinoceros unicornis) in Nepal. Ecological Applications, 19, 1693-1707.

Revol, B. (1995) Crocodile farming and conservation, the example of Zimbabwe. Biodiversity and Conservation, 4, 299-305.

Robinson, J., Cochrane, G. \& Loeffler, K. (2007) Discussion regarding the impacts of bear bile farming on wild bears in China and Vietnam. In Proceedings of the Fourth International Symposium 
on the Trade in Bear Parts (ed. D.F. Williamson), pp. 67-73. TRAFFIC East Asia-Japan, Tokyo, Japan.

SAlter, R.E. (1993a) Observations on Wildlife Trophies and Trade in Lao PDR, 1988-92. Unpublished report. IUCN, Vientiane, Lao PDR.

SAS-ROlfes, M. \& Conrad, K. (2010) Making sense of the tiger farming debate. Http://indefenceofliberty.org/story/3953/3985/ Making-sense-of-the-tiger-farming-debate [accessed 25 May 2013].

Scotson, L. (2010) Distribution and status of Asiatic black bear and Malayan sun bear in Nam Et Phou Louey National Protected Area, northern Lao PDR. International Bear News, 19, 14-16.

Scotson, L. (2012) Status of Asiatic black bears and sun bears in Xe Pian National Protected Area, Lao PDR. International Bear News, 21, 8-11.

SCHNEIDER, J.L. (2008) Reducing the illicit trade in endangered wildlife: the market reduction approach. Journal of Contemporary Criminal Justice, 24, 274-295.

Tizard, R., Davidson, P., Khounboline, K. \& Salivong, K. (1997) A Wildlife and Habitat Survey of Nam Ha and Nam Kong Protected Areas, Luang Namtha Province, Lao PDR. Unpublished report. Wildlife Conservation Society, Vientiane, Lao PDR.
TONG, D. (2007) Understanding the motivations of wildlife consumption. In The State of the Wildlife Trade in China: Information on the Trade in Wild Animals and Plants in China (eds H. Xu \& C. Kirkpatrick), pp. 18-25. TRAFFIC East Asia, Beijing, China.

Vu, Q.T. (2010) An Analysis of Attitudes and Bear Bile Use in Vietnam. Education for Nature, Hanoi, Vietnam.

Zimmerman, M.E. (2003) Black market for wildlife: combating transnational organized crime in the illegal wildlife trade. The Vanderbilt Journal of Transnational Law, 36, 1667-1689.

\section{Biographical sketches}

CHRis R. SHEPHERD has worked on wildlife trade and related conservation issues in South-east Asia for the past 2 decades, and is especially interested in bears. EmILY LIVINGSTONE is a pen name as the co-author wishes to remain anonymous. His/her research interests lie in the monitoring and sustainable use of wildlife. 